\title{
QUEEN'S
UNIVERSITY
BELFAST
}

\section{Varieties of Economic Crisis, Varieties of Ideational Change: How and Why Macroeconomic Policy and Financial Regulation Differ}

Baker, A. (2015). Varieties of Economic Crisis, Varieties of Ideational Change: How and Why Macroeconomic Policy and Financial Regulation Differ. New Political Economy, 20(3), 342-366.

https://doi.org/10.1080/13563467.2014.951431

Published in:

New Political Economy

Document Version:

Peer reviewed version

Queen's University Belfast - Research Portal:

Link to publication record in Queen's University Belfast Research Portal

Publisher rights

Copyright 2014 Taylor \& Francis.

This is the accepted manuscript version. The final publisher edition can be found here:

http://www.tandfonline.com/doi/full/10.1080/13563467.2014.951431\#.VC6Kn_IdWWU

\section{General rights}

Copyright for the publications made accessible via the Queen's University Belfast Research Portal is retained by the author(s) and / or other copyright owners and it is a condition of accessing these publications that users recognise and abide by the legal requirements associated with these rights.

Take down policy

The Research Portal is Queen's institutional repository that provides access to Queen's research output. Every effort has been made to ensure that content in the Research Portal does not infringe any person's rights, or applicable UK laws. If you discover content in the Research Portal that you believe breaches copyright or violates any law, please contact openaccess@qub.ac.uk. 


\section{Varieties of Economic Crisis, Varieties of Ideational Change: How and Why financial regulation and macroeconomic policy differ}

\section{(Conditional acceptance, New Political Economy).}

Partly because of the historical experience of the great depression of the 1930s and the stagflation of the 1970s, much political economy scholarship associates episodes of financial and economic crises with far reaching ideational change (Blyth, 2002, Helleiner, 2010, Hall, 1993, Hay, 1996, 2011, Gamble, 2009). One important contribution draws attention to a process of 'persuasive struggle' between elites and mass publics that crises ignite, as agents compete for the right to define the nature of that crisis and how to respond by forwarding interpretations and arguments drawn from particular intellectual frames (Widamier, Blyth and Seabrooke, 2007, Blyth, 2002). What has been missing from the existing literature on ideational change at times of crises however, is a sense of how these processes of persuasive struggle, and how the success of those 'norm entrepreneurs' arguing for ideational change is shaped by two contextual variables: the most immediate material symptoms and problems that a crisis displays (the variety of crisis); and the institutional character of the policy subsystem that agents have to operate within to affect change. Introducing these two variables into our accounts of persuasive struggle and ideational change enables us to deepen our understanding of the dynamics of ideational change at times of crisis. This is important and relevant for our understanding of the political economy of the recent financial crash, because a quite rapid and radical intellectual change has been evident in the field of financial regulation in the form of an embrace of a macroprudential frame (Borio, 2009, 2011, Baker 2013a, 2013b, Goodhart, 2014). In contrast in the field of macroeconomic policy - both monetary and fiscal policy, many pre-crash beliefs remain prominent, there is evidence of ideational stickiness and inertia, and despite some policy experimentation, overarching policy frameworks and their rationales have not as yet been overhauled (Farrell and Quiggin, 2012, 
Blyth, 2013a, 2013b Dellepiane-Avellaneda, 2014, Hodson and Mabbett, 2010, Clift, 2014). In this respect, why some ideas change at times of crisis and in some policy areas but not in others, and why some ideas are successful in taking root in certain circumstances and not in others, are questions that require more attention in the field of political economy (Chwieroth, 2010). This article addresses these questions by focusing on the context in which actors or 'norm entrepreneurs' arguing for change operate, and how that context effects their strategies and success. Norm entrepreneurs are individuals, usually with expert technical knowledge, who construct cognitive frameworks to give meaning to events such as economic crisis, and generally promote these frameworks and ideas out of a sense of genuine ideational commitment,' because they genuinely believe in a set of ideas, even if they have no immediate material impact on their own well-being (Finnemore and Sikkink, 1998, p.897898), although this should not rule out the possibility that individuals can act in a more instrumental fashion and promote ideas that favour the institutions they represent.

The article applies Peter Hall's framework of three orders of policy changes to help illuminate and explain the variation in patterns of change in the fields of financial regulation and macroeconomic policy since the financial crash of 2008 (Hall, 1993). First, applying Hall's framework of three orders of change helps us to identify that radical intellectual change in financial regulation appears to proceed much more quickly than radical macroeconomic intellectual change. Second, it illustrates how the sequencing of ideational change is different in financial regulation than in macroeconomic policy. Third, it illuminates that experts and technocrats have more scope to affect radical intellectual change in financial regulation, but are more constrained in terms of detail and practical policy implementation, whereas the evidence points in the opposite direction in macroeconomic policy, with technocrats having more autonomy over the detail of policy, but less in setting broader intellectual frames. Ultimately, it is argued that both policy areas respond to different 
varieties of crises in different ways because of their contrasting political and institutional characteristics, with financial regulation likely to respond to dramatic, explosive banking crises, because it is easier for norm entrepreneurs to make a plausible case for regulatory change in such circumstances that will have intuitive appeal to a range of actors. Macroeconomic policy is more likely to respond to slow burning crises of progressive macroeconomic underperformance, making profound intellectual change in macroeconomic policy a much slower long term process, as time is required for the case for change to be assembled and for it to become appealing to the plurality of actors required to make it politically viable. Ideational change is therefore not only mediated and shaped by institutional context (Bell, 2011), but norm entrepreneurs' capacity to promote ideational change is constrained by the material symptoms of crisis, which will shape the intuitive appeal of their arguments to a range of other actors (Widmaier, Blyth and Seabrooke, 2007).

While the argument developed here does draw attention to different varieties of economic crisis and their symptoms, unlike accounts of varieties of economic crisis in the economics literature (Reinhart and Rogoff, 2008,) we cannot afford to focus solely on the material economic manifestations and features of crisis alone. Rather a genuine political economy of crises has to examine the interactions between the material financial and economic symptoms of crisis and how the process of political and intellectual construction of crisis proceeds through persuasive struggles and the assembling of viable political coalitions, as undertaken by norm entrepreneurs. I first raise the prospect that contemporary financial regulation and macroeconomic policy are characterised by different ideational patterns since the financial crash of 2008. I then seek to explain this by contrasting the dynamics of exceptional macroeconomic change in the 1970s in Britain, with exceptional financial regulatory change since the 2008 crash. Finally, I ask what the implications of this analysis 
might be for the patterns of institutional and ideational politics surrounding macroeconomic policy in the current period.

\section{Financial Regulation and Macroeconomic Policy on Divergent Policy Tracks?}

One of the most intriguing and potentially illuminating statements made by a policy maker in the post 2008 crash era, was made by the Bank of England's former Deputy Governor, Paul Tucker. In a 2011 speech, Tucker stated:

"we needed to think about markets somewhat differently when we are doing monetary policy and financial stability. For monetary policy in most circumstances, it is a reasonable default assumption that core markets are more or less efficient most of the time. So while we absolutely have to be alert to distortions, we are not crazy to infer from yield curves, expectations about the path of policy rates or of inflation. But for financial stability (regulation), which of course affects macroeconomic conditions, I have always encouraged the team to do a 'Gesltalt flip' to think of markets as inefficient, riddled with preferred habitats, imperfect information, regulatory arbitrage, herding and inhabited by agents with less than idealised rationality" (Tucker, 2011, pp.3-4).

This statement is interesting and potentially illuminating because it indicates that central banks are characterised by a degree of intellectual pragmatism and that the ideational and institutional politics in the area of macroeconomic policy and financial regulation might be quite different.

It is now widely accepted in regulatory circles that over reliance on banks' Value at Risk (VaR) models that revolved around market prices and the subsequent monitoring of those models by supervisors, was one of the weaknesses of the pre-crash regulatory regime (Turner, 2011, Persaud, 2009, Brunnermeir at al 2009, FSA, 2009, FSF, 2009, Panetta et al, 2009, Youngman, 2009, Goodhart, 2005, Borio, Furfine and Low, 2001). Market prices were assumed to be driven by the rational interaction of multiple independent agents and market risk was therefore mathematically modelable. These beliefs informed regulatory practice, as 
greater transparency, more disclosure and more effective risk management by financial firms based on market prices became the cornerstones for the regulation of supposedly efficient markets (Eatwell, 2009, Turner, 2011). All of this was largely justified by the arguments of new classical economists such as Robert Lucas, that if human beings are rational in their preferences, choices and expectations then the macroeconomy would have a strong tendency towards equilibrium (Lucas, 1980), as well as Eugene Fama's efficient markets hypothesis that liquid financial markets were characterized by the efficient processing of all available information, making the actual price of a security a good estimation of its intrinsic value (Fama, 1970). In the words of the chair of the UK's Financial Services Authority, Lord Adair Turner, in the pre-crash period, a simplified version of the efficient markets hypothesis became part of the regulatory 'institutional DNA' (Turner, 2011,) The financial collapse of 2007-8, as Tucker himself concedes, revealed that 'securities were fundamentally mispriced (Tucker, 2011, p.3)' and that markets and the agents that constitute them do make ex ante mistakes ( p.2), questioning the claims of the 'rational expectations paradigm' that has dominated economics since the 1970s (Tucker, 2011, p.2). Armed with efficient markets assumptions, supervisors, in the pre-crash period, focused on assessing and evaluating the risk management models and procedures of individual banks (Tsingou, 2008). Since the crash and in recognition that financial markets are prone to procyclicality, that herding is common behaviour, and that financial complexity and innovation can engender inherent financial instability, regulators throughout the world are now seeking to build macroprudential regulatory regimes based on macro level countercyclical interventions intended to limit systemic risk and endogenous financial instability, in a significant and intellectually radical macroprudential ideational shift (Baker, 2013a, 2013b, Baker and Widmaier, 2014).

There is a curious tension in Tucker's statement about the different assumptions underpinning regulatory policy and monetary policy. The discrepancy between the two policy 
areas is not just a case of simply altering a variable in a model. Rather it is the fundamental assumption about how the financial world is actually constituted and functions, and about the behaviour of economic agents and of the implications of this for wider economic and market systems. If the Bank's assumption about financial markets generally being myopic, prone to instability and characterised by herding is the correct one, why is it reasonable to use an opposite and diametrically opposed assumption as the basis for monetary policy, when in the admission of key Bank personnel it is an inaccurate representation of how financially markets actually function? Moreover, this situation is not just specific to the Bank of England. For officials at the Bank for International Settlements (BIS), who pushed the movement towards macroprudential regulatory philosophies, since the crisis, 'macroeconomic policy has one language, while financial stability policy now has a different language, and this situation is not 'tenable' (Confidential interview conducted with BIS official, Basel, 07 February 2014.) While central banks have been willing to change 'their beliefs about the self equilibrating properties of markets' in relation to regulatory and financial stability policy, they have been reluctant to do likewise in relation to monetary policy (Confidential correspondence with BIS official, 12 February 2012) ${ }^{1}$

If we revisit the justification for the current monetary policy framework in the UK, introduced in 1997 by the New Labour government, to give operational independence to the Bank of England to set interest rates to meet a pre defined inflation target, it revolved around the need to achieve credibility through 'pre commitment,' maximum transparency and constrained discretion by facing down 'time inconsistency' (Balls, 1998). In other words, the framework was justified by the need to signal 'good future intentions' to rational economic agents. Moreover, reaching judgements on what may happen to inflation requires a degree of formal modelling and forecasting that requires an assumption that agents will respond rationally to future price signals. In this sense, the assumption in monetary policy has served 
the Bank of England and other central banks rather well. However, when we contrast this with the position the Bank adopts in financial regulation, it would also appear to be a convenient and pragmatic fiction. In this sense, the first assumption outlined by Tucker, provided the justification for expanding the Bank's powers to set interest rates and to target a pre assigned measure of inflation. It is therefore easy to see why the Bank continues to be wedded to such assumptions in the field of monetary policy, because it is central to its pivotal role in monetary policy making. For example, only in the first half of 2014 has Governor of the Bank of England, Mark Carney begun to openly question the UK's inflation targeting regime as a potential distraction, some five and half years on from the peak of the financial distress that shook the prior efficient markets orthodoxy, suggesting there has been resistance to learning in the field of monetary policy and that this process has proceeded very slowly (Carney, 2014). Moreover, Bank personnel have invested considerable time, energy and their professional futures in models, data and forecasting designed to make the existing monetary policy framework function. In financial regulation, exactly the opposite applies. The Bank was stripped of its regulatory responsibilities by the 1997 legislation, but is now seeing an expansion in its regulatory role. The assumption that markets are prone to irrationality, myopia and herding, provides a justification for more intrusive forms of regulation that focus more directly on the business models and practises of private institutions, allowing the Bank to be much more assertive in relation to the financial industry. The Bank is a direct beneficiary of this change in assumptions, as the new Financial Policy Committee (FPC) has been given power to alter and raise counter cyclical capital requirements, sectoral capital requirements and to make recommendations regarding new regulatory rules (Tucker, 2011, p. 4). Therefore while central banks have had institutional incentives to challenge efficient market thinking in the field of financial regulatory policy, they also have institutional incentives to favour inertia in the field of monetary policy. While this is a clear and attractive 
explanation for the different patterns of post-crash ideational change in macroeconomic and financial regulatory policy, it is also a partial and simplistic one, because central banks do not determine policy outcomes in either field in isolation and have little input into fiscal policy, which also appears to have displayed some intellectual continuity being guided by notions of crowding out, Ricardian equivalence and the expansionary potential of fiscal contraction (Blyth, 2013).

\section{The UK's Macroeconomic Paradigm Shift in the 1970s}

Peter Hall's work on British macroeconomic policy highlighted a number of features that potentially tell us a great deal about the institutional and policy dynamics of macroeconomic policy change (Hall, 1993). Hall distinguished between three orders of policy change: the ideas and assumptions that inform and set the overarching objectives of policy in a given area (third order change): the institutional arrangements and instruments used to achieve those objectives (second order change): and the precise settings of those instruments in quantitative or numerical terms (first order change) (Hall, 1993). Hall used the notion of third order change to denote radical change in the overarching terms of policy discourse, in the hierarchy of goals behind policy (Hall, 1993, p.279) and in causal assumptions or accounts of how the world facing policy makers actually works (Hall, 1993, p.280). He associated this kind of change with a Kuhnian 'paradigm shift' (Kuhn, 1996). Thomas Kuhn of course, famously compared scientific paradigms to a Gestalt or an interpretative framework of terminology and assumptions, which are influential precisely because so much of them are taken for granted and resistant to scrutiny. From time to time, the policy and regulatory process Hall argued, is characterized by a shift from one policy frame to another, - third order change. Kuhn referred to this process of moving from one paradigm to another as a 'Gestalt flip', when underlying 
assumptions about aspects of the world are overturned and replaced with a different, or diametrically opposed set of assumptions about how things are actually constituted, as in Paul Tucker's use of the term to distinguish the differing assumptions the Bank of England adopts in monetary policy and financial regulation.

Hall developed the idea of third order change based on an examination of the shift from Keynesian to Monetarist macroeconomic policy making in Britain during the 1970s. While macroeconomic policy in Britain was occasionally at least partially pragmatically Keynesian in outlook since 1979, (Clift and Tomlinson, 2007, Oliver and Pemberton, 2004), as Oliver and Pemberton note, this overlooks that there was a basic trajectory change in British macroeconomic policy and UK political economy more generally, that was driven in part by a change in dominant economic ideas, heralding three decades of market oriented neoliberalism (Oliver and Pemberton, 2004). For former British Chancellor of the Exchequer, Nigel Lawson, under the Keynesian frame the objective of macroeconomic policy was to generate growth through stimulus and fiscal expansion, while the objective of microeconomic policy was to contain inflation through incomes policy. Under the Thatcher governments these roles were reversed. Microeconomic policy was used to generate growth through structural reform, privatisation, labour and financial market deregulation and the removal of red tape, allowing business and entrepreneurs as 'supply side heroes,' to expand and become more profitable, in accordance with Say's Law that supply generates its own demand. In contrast after 1979 macroeconomic policy concentrated on stabilising inflation, rather than on growth and reducing unemployment (Lawson, 1992).

In Hall's analysis the shift from Keynesian policy in Britain was characterised by three very specific features. These are time or duration, sequencing and political and institutional context. These variables are laid out in table 1 . 


\section{Time: A slow burning crisis of stagnation}

First, relating to time or temporal dynamics the shift was a protracted process played out over six years from 1973 to 1979 . The Keynesian paradigm according to Hall was characterised by the progressive accumulation of anomalies from 1973 onwards (Hall, 1993). This was most notable in the occurrence of stagflation, - a simultaneous increase in inflation and unemployment, - a phenomenon that was not fully comprehensible within the terms of the existing paradigm, and in Hall's terms, appeared to 'vitiate the Phillips curve' (Hall, 1993, p.285). However, wholesale third order change and the formal abandonment of Keynesian objectives, only transpired some six years later following the election of Margaret Thatcher in 1979 (Hall, 1993, p.283.) In other words, the crisis of the 1970 s was very much a slow burning long term economic crisis of stagnation, persistent lack of growth and progressively rising inflation, as increments of Keynesian reflation appeared to become progressively less effective, resulting in a number of policy mistakes that appeared to make the situation worse, 'stretching the intellectual coherence of the existing paradigm to the point of breaking' (Hall, 1993, p.285). Balance of payments problems, rapid inflation, mounting external debt, poor government finances, repeated pressure on Sterling and growing trade union unrest all combined. These problems were eventually constructed as a crisis of an 'overloaded' and oversized state, of the excess power of organised labour, of rising prices and wages, and ultimately of an exhausted prevailing macroeconomic model (Hay, 1996.) Monetarism provided an intellectually coherent and politically appealing critique of the status quo to factions within the Conservative party, as Keynesian policy makers at the Treasury gradually lost their authority and credibility on economic policy to an outside market place of economic ideas (Hall, 1993, p.286). However, this process itself took several years, as social learning proceeded slowly, reflecting the slow burning nature of economic stagnation and persistent 
inflation, the need to interpret these problems and to build political coalitions to support such an interpretation. One potential hypothesis that comes out of Hall's work on macroeconomic policy therefore, is that far reaching macroeconomic ideational change is likely to be a relatively long term process and is most likely to be catalysed by a long running, slow burning crisis of persistent poor macroeconomic performance. Such crises are often complex, involving several interrelated features such as rising inflation, economic stagnation and poor growth, balance of payments problems and rising budget deficits as in the 1970s case. Making the causal connections, working out a narrative and advancing a series of coherent prescriptions and a policy framework to address such a complex range of problems can therefore take several years. Moreover, such a case for change will require recognisable empirical evidence of persistent long running problems over several years if the case for far reaching macroeconomic change is to become persuasive to a critical mass of actors.

\section{Policy Sequencing}

Second, Hall's analysis suggested that sequencing and prior policy experimentation is a precondition for far reaching macroeconomic third order change. In the period, from 19731979, successive UK governments experimented in the form of first and second order changes, before new third order objectives were formally embraced by the Thatcher government in 1979. Some of these policies, such as the new system for controlling public expenditure - 'cash limits' and the removal of quantitative controls on lending in the financial system, had a distinctly non-Keynesian orientation (Hall, 1993, p.278). Third order change involved a specific $1+2=3$ (eventually) sequence, as a process of ad hoc experimentation with policy measures outside of the normal Keynesian frame ensued. This sequence is further illustrated in table 1. Policy experimentation of this kind preceded a 
formal third order shift and the embrace of a new set of objectives such as controlling inflation and targeting measures of the money supply. For Hall, a paradigm shift had to involve a simultaneous shift in all three types of policy. This could only be said to have materialised once the Thatcher government's formally embraced monetarist ideas and assumptions in 1979, as controlling inflation and the money supply became the principal declared objective at the centre of their new macroeconomic programme and policy frameworks. Prior experimentation from outside of the dominant frame increased the perception that the old policy frame was redundant and had essentially ceased to function in the way intended. Thus prior prolonged policy experimentation increased the strength of arguments calling for a new policy frame.

\section{Institutional and Political Context}

Third, Hall drew attention to the political nature of the paradigm shift and how it was influenced by the institutional context for the conduct of macroeconomic policy, arguing that third order change was 'more sociological than scientific,' involving a set of society wide judgments more political in tone. In particular, third order macroeconomic change required politicians reaching a judgment on which group of experts to regard as 'authoritative' (Hall, 1993, p.280). In Hall's account third order change in British macroeconomic objectives in the 1970s was promoted by an alliance of politicians, think tanks and influential journalists such as Sir William Rees Mogg and Samuel Brittan, who all cultivated and sought to build public support for their arguments, but ultimately depended on the conversion of senior figures in the Conservative Party such as Mrs Thatcher (Hall, 1993, pp.286-287). In contrast, the development of first and second order changes to particular macroeconomic instruments, and their quantitative settings, in the prior $1+2$ phase of experimentation were much more 
technical matters. They were, Hall notes, carried out almost exclusively by technocrats and civil servants with little input from politicians, or wider political actors (Hall, 1993, p.281). This suggests that the detail of macroeconomic policy tends to be less politically contentious than a formal announcement of changes in underlying assumptions, overarching objectives and a corresponding redesign in policy frameworks.

Notably, macroeconomic policy is always a central plank of any aspiring governing party's programme to govern and a key part of its communications with the electorate. Approval of third order change in this area, in turn requires widespread political support and understanding. In most countries macroeconomic policy resembles what James Thurber has referred to as a macropolicy system, - general policy decisions with major political effects involving broad public interests, visibility, divisiveness, high media coverage and many participants (Thurber, 1996 p.77.) In such policy systems consensus building in favour of far reaching change tends to be a slow process due to the sheer number of actors that have to be convinced and the fact third order macroeconomic change appears to depend on electoral campaigning calculations and cycles.

\section{Table 1}

\begin{tabular}{|l|l|l|}
\hline Feature & Macroeconomic Policy & Financial Regulation \\
\hline First order Change & Quick, technocratic. & Slow, political \\
\hline Second Order Change & Quick, technocratic & Slow, political \\
\hline Third Order Change & Slow, political & Quick, technocratic \\
\hline Type of Crisis & $\begin{array}{l}\text { Slow burning - economic } \\
\text { stagnation }\end{array}$ & $\begin{array}{l}\text { Dramatic and explosive - } \\
\text { financial system malfunctions }\end{array}$ \\
\hline
\end{tabular}




\begin{tabular}{|l|l|l|}
\hline Sequence & $1+2=3$ & $3=2+1$ \\
\hline
\end{tabular}

In summary there are three implications of Hall's analysis for third order macroeconomic change. First it is easier for norm entrepreneurs to make causal connections to macroeconomic policy and appeal to the intuitions of other actors, when crises take the form of a long term, slow burning crisis that is suggestive of long term poor macroeconomic performance. Second, prior policy experimentation in the form of $1+2=3$ sequence appears to be part of the process of achieving macroeconomic third order change as an old paradigm breaks down due to accumulated anomalies (see table 1). Third, third order ideational change in the field of macroeconomic policy is likely to require learning and consent from actors outside of narrow expert groups, including senior political figures and their constituencies, and the process of building the necessary consent and agreement takes time.

\section{The Macroprudential Third Order Ideational Shift of 2009}

It is now widely acknowledged by academics and policy makers that a macroprudential ideational shift emerged from the financial crash of 2008 (Borio, 2009, 2011, Baker, 2013a, 2013b, Persaud, 2010, Haldane, 2009, 2013, Datz, 2013, Goodhart, 2014, Hanson, Kyap and Stein, 2011). Since 2009, when endorsement for a macroprudential policy framework made its way into various G20 communiqués, new policy committees have been established to implement macroprudential policy in the United State (Financial Stability Oversight Council FSOC), in the United Kingdom (Financial Policy Committee FPC) and the European Union (European Systemic Risk Board ESRB). Furthermore, the Basel III agreement made provisions for countercyclical capital buffers as a macroprudential policy instrument. The 
macroprudential perspective reverses many of the claims of the efficient markets position by denying that individually rational self-interested investment strategies are likely to produce financial stability and equilibrium, identifying finance's inherent procyclical tendencies, the propensity for herd behaviour amongst investors and the destabilising effects of financial complexity (Borio, 2009, Baker, 2013b). The macroprudential ideational shift through its assumptions about the behaviour and properties of financial markets, justifies a regulator intervening with countercyclical policy measures to restrain and direct market activities on a system wide basis. Macroprudential policy involves using prudential measures (a variety of capital requirements, both price based and quantity based instruments) for macroeconomic ends, or seeking to protect the real economy from financial excess and instability (Haldane, 2014a, 2013²).

Viewed in terms of Hall's criteria, the adoption of macroprudential regulatory objectives, assumptions and language can be viewed as an example of third order change. According to Hall's criteria, third order change requires a radical change in the overarching terms of policy discourse, in the hierarchy of goals behind policy and in causal assumptions or accounts of how the world facing policy makers actually works. The macroprudential shift fits all three of these criteria. First, Hall points out that policy makers work within a framework of ideas and standards that specify the very nature of the problems they are meant to be addressing. Like a Gestalt, this framework is embedded in the very terminology through which policy makers communicate about their work (Hall, 1993, p.279.) In the world of financial regulation, macroprudential is the new Gestalt. As Claudio Borio of the BIS, has astutely observed of his regulatory peers, they are 'all macroprudentialists now,' at least in terms of broad agreement on the need to develop macroprudential policy instruments and regulatory regimes and the importance of combatting destabilising systemic risk (Borio, 2009). Notably, Macroprudential research has become a growth industry. The BIS, the 
International Monetary Fund and the Financial Stability Board are regularly producing reports and papers on various aspects of macroprudential policy (FSB/ IMF/ BIS, 2011). The Bank of England has created a macroprudential strategy division to support the decision making of the FPC, while the European Central Bank (ECB) has created the Macroprudential Research Network (MaRS) to develop core conceptual frameworks, models and tools in order to improve macroprudential supervision and research, including over 180 researchers from the ECB and EU national central banks, and academic economists from Europe and the United States. In this sense, in Vivien Schmidt's terms, 'macroprudential' can be conceived of as a 'co-ordinative' discourse that organises experts, through a 'programme', that sets the underlying organising principles and frames of reference that define the problems to be solved by policies, the issues to be considered, the goals to be achieved, the norms, methods and instruments to be applied (Schmidt, 2008).

Second, there has been a movement from a microprudential approach focused solely on evaluating the safety of individual institutions and their VaR models, to viewing risk as a systemic and endogenous property requiring system wide regulatory policy instruments and interventions to constrain and steer private risk taking and investment strategies as part of new macro stabilisation efforts to protect the wider economy from the excesses of the financial sector. Moreover, its stronger advocates have suggested the real social purpose of macroprudential regulation is to make finance more socially useful, better serving the real economy, so that finance becomes the 'servant rather than the master' (Haldane, 2012, 2014b Turner, 2011, Lothian, 2011). There is therefore scope for representing the emergence of macroprudential regulation as a substantial change in the hierarchy of policy goals from micro-supervision to macro-level systemic intervention, stabilisation, management and direction. Third, macroprudential's assumptions about endogenous and endemic financial instability, draw heavily on the ideas of Hyman Minsky, representing a radically different 
position from the Eugene Fama inspired pre-crash efficient markets position (Baker, 2013a, 2013b, Turner, 2011, Barwell, 2013). As Paul Tucker's statement, discussed earlier in this paper indicates, the movement from assuming that financial markets will produce stable efficient outcomes, to recognising their propensity to generate instability and negative societal wide externalities, changes the foundational assumptions at the core of financial regulation, and represents a 'Gestalt flip' from the prior efficient markets orthodoxy, a process Hall himself associates with third order change (Hall, 1993).

The implication of this is that the macroprudential ideational shift has switched the cognitive filter employed by policy makers to a quite different setting. Policy makers are now using various macroprudential rationales to inform and guide regulatory initiatives and practice. The effect of this change is to bring a whole range of practical policy instruments within reach, which were previously cursorily dismissed and not even seriously debated or considered as a consequence of the dominance of the efficient markets perspective (Baker, 2013). These include: countercyclical capital requirements; dynamic loan loss provisioning; countercyclical liquidity requirements; administrative caps on aggregate lending; reserve requirements; limits on leverage in asset purchases; loan to value ratios for mortgages; loan to income ratios; minimum margins on secured lending; transaction taxes; constraints on currency mismatches; capital controls; and host country regulation (Elliot, 2011). Possibly, the most intriguing thing about the macroprudential ideational shift however, is that it can be seen to reverse every one of the three characteristics of the third order change in macroeconomic policy in the UK, identified by Hall (see table 1).

Time: Dramatic, Explosive Crisis 
First, in contrast to the long run process of macroeconomic experimentation in Hall's case, the rise of macroprudential thinking from the margins to the centre of the policy agenda was rapid and took place in under a year. From the peak of the financial distress in the Autumn of 2008, the adoption of a macroprudential frame for financial regulation was confirmed in a time period of a little over six months. The early centre piece international policy document responding to signs of distress in securities and derivatives markets, - a report by the Financial Stability Forum in April 2008 (FSF 2008), - re-iterated 'the familiar trilogy' (Eatwell, 2009), of 'greater transparency, more disclosure and more effective risk management' by banks and investment funds (FSF, 2008). However, exactly one year later the Horsham G20 communiqué was openly advocating counter cyclical capital buffers and policies designed to 'mitigate the procyclicality' of the financial system, while the London G20 summit communiqué called for the development of macroprudential regulation $(\mathrm{G} 20$, 2009a, 2009b). In a period of little over six months, macroprudential ideas moved from relative obscurity in certain enclaves of the Bank for International Settlements (BIS), to the centre of the policy agenda, dominating and driving the post crisis financial reform debate, in the international community of central bankers, (Borio, 2011, Haldane, 2009, Tucker, 2011, Bernanke, 2011, Constancio, 2011, FSB/IMF/BIS, 2011, Baker 2013a).

The events of 2007-08 were dramatic as asset values collapsed, liquidity dried up, credit markets froze, interbank lending markets ground to a halt, several financial institutions became insolvent and many others required public financial support of various descriptions to continue trading. These dramatic events appeared to provide empirical disconfirmation of the efficient markets perspective, but they also created a sense of urgency for policy makers and politicians to be seen to be doing something in order to respond to rapidly unfolding events by taking affirmative action with a new policy programme, whose constituent concepts seemed to predict and provide a framework for explaining and accounting for financial 
instability (Persaud, 2010). There was consequently an imperative and pressure to be seen to be taking action quickly. Notably, linking the symptoms of financial distress, malfunctioning banking systems and frozen inter-bank markets to the destabilising systemic dynamics of financial markets and the failure of existing approaches to financial regulation has an intuitive appeal. In contrast, linking the crisis to macroeconomic causes by highlighting global imbalances, the limits of a narrow focus on inflation, excessive inequality and or a broken growth model, are much more complex intellectual arguments that have to specify a longer and more elaborate causal chain, and have far less immediate intuitive mass appeal. Not only do they take longer to work out, but the act of persuasion that has been agent based constructivism's focus (Widmaier et al, 2007), also becomes a longer and more time consuming process.

After the extreme events of the Autumn of 2008, existing expert regulatory policy networks moved swiftly to seek fill the policy vacuum left by the crash, by drafting a series of policy reports that diagnosed the crisis and developed reform proposals (Seabrooke and Tsingou, 2014, Baker 2014a). Moreover, by delegating a number of reporting tasks to the Financial Stability Forum (FSF), later to become the Financial Stability Board (FSB), G20 politicians essentially turned to the same expert networks that had designed pre-crash regulation, which in part was an acknowledgement of the technical and complex nature of the questions posed by the malfunctioning of modern, sophisticated financial markets. A number of key experts policy reports followed: the Turner Review (UK); the Geneva Report; the European Commission-instigated De Laroisiere report; the United Nations Stiglitz Commission report; a G30 report; and reports by the Financial Stability Forum (FSF). All called for macroprudential regulation and all of them were published in the first half of 2009 (FSA 2009; Brunnermeir et al. 2009; De Laroisiere 2009; UN 2009; G30 2009; FSF 2009.) In this sense, the macroprudential ideational shift resembled what Finnemore and Sikkink have 
referred to as a 'norm cascade' as expert reports repeatedly made the macroprudential case (Finnemore and Sikkink, 1998).

Crucially, macroprudential ideas and arguments already had a key foothold in international central bank policy networks. Notably, some staff at the BIS (a source of analysis and banking services for central banks) had spent the early 2000s developing macroprudential foundational concepts such as procyclicality (Borio, Furfine and Lowe, 2001, Borio, 2003, Borio and White, 2004, White, 2006, BIS 2006, Clement, 2010). They had been aided by eminent academic economists such as Charles Goodhart and Hyun Shin who had been undertaking similar work (Goodhart and Segoviano 2004, Morris and Shin, 2004). Macroprudential ideas had in the words of Claudio Borio of the BIS, been 'evolving quietly in the background, known only amongst a small but growing inner circle of cognoscenti' (Borio, 2011, p.1). Consequently, macroprudential ideas had a prior intellectual and institutional presence, particularly at the BIS and amongst a small fraternity of economists. Despite being marginal in the pre-crash period therefore, the macroprudential perspective did have the strategic advantage of access to the established financial technocratic research and report writing machinery that politicians called upon to provide them with diagnoses, answers and proposals. Spotting the window of opportunity provided by the financial crisis to promote their earlier work in late 2008 and early 2009, BIS officials deliberately mobilised a campaign of advocacy, including, at the instigation of the new General Manager Jaime Caruana, pushing for macroprudential regulation to be on the G20 agenda (Confidential interview with BIS official, 7 February 2014). At the same time, the Bank of England had an in-house financial stability team that had worked on macroprudential issues since 2004 , but chose to avoid publicly discussing these matters, because of the prevailing climate of opinion, and a recognition there was little point in putting this analysis in play because there would not be much of an audience for it both 
within the Bank, but also outside, particularly in the United States. However, as explained by one Bank of England official, "this meant when the balloon went up, we already had the ideas in our knap sack. We had already discovered religion" (Confidential interview Bank of England Official, 10 December 2013.) Consequently, the macroprudential perspective had an advantage in terms of institutional access and a body of prior work that outlined the inadequacies of the prior efficient markets orthodoxy. Its emphasis on the systemic, procyclical and unstable dynamics of financial markets, provided a ready made conceptual apparatus for explaining the events of Autumn 2008. This effectively made the macroprudential perspective an off the shelf set of proposals that could be presented to politicians and senior policy makers (Confidential interview BIS official, 7 February 2014). These factors of prior intellectual and institutional presence help to explain the relatively rapid nature of the macroprudential ideational shift.

\section{Policy Sequencing}

Second, the sequencing at work in the case of the macroprudential ideational shift was exactly the reverse of that evident in the case of UK macroeconomic policy in the 1970s. There was no process of sustained prior policy experimentation with first and second order policy change from outside of the efficient markets perspective, with the exception of the odd isolated case $\mathrm{e}^{3}$. Rather than a sequence of $1+2=3$, the macroprudential shift, has involved a move straight to 3, prior to first and second order policy experimentation. The significance of this is that macroprudential policy is currently in a highly experimental phase of first and second order policy development, as countercyclical capital buffers and loan to value ratios and other policy instruments are developed and tested. As officials at the Bank of 
England note, "the state of macroprudential policy resembles the state of monetary policy just after the second world war, with patchy data, incomplete theory and negligible experience, meaning that MPR will be conducted by trial and error" (Aikman, Haldane, and Nelson, 2011). This makes the macroprudential ideational shift a highly contingent one, but also an interesting test case for assessing whether a $3=2+1$ sequence can be sustained without prior first and second order policy experimentation, or whether successful paradigm shifts always have to follow the $1+2=3$ sequence first identified by Hall (Baker, 2013a)..

For BIS officials involved in pioneering the conceptual frame of macroprudential regulation, a conceptual framework was first required to provide guidance for how policy instruments could be used (Correspondence with official, 12/02/12.) One reason for this reversed sequencing is that macroeconomic policy often requires forms of policy experimentation. The slow burning and non-dramatic nature of macroeconomic crises means that as in Hall's case, existing policy frameworks often gradually accumulate anomalies and cease to function as intended, necessitating, but also allowing the time and space for incremental and ad hoc experimentation. In contrast, financial regulation is directly concerned with financial markets, which can be volatile and conditions can change suddenly. This means conceptual understandings of their functioning can break down much more quickly and also have to be revised much more hastily. In the pre-crash period, because regulators in leading financial centres like the US and UK were very content with the prevailing efficient markets light tough approach to financial regulation, it meant that advocates of an alternative view such as staff at the BIS, who wield influence through the provision of analysis, had to first develop conceptual work, outlining and further developing concepts such as procyclicality, as a rationale for the use of countercyclical policy instruments, if they were to ever stand a chance of persuading their client states and central 
banks to take macroprudential regulation seriously (Correspondence with the author, 12/02/02.).

\section{Institutional and Political Context}

Third, macroprudential ideational change was promoted by insider technocrats largely operating in established expert regulatory networks, which in the world of central banking and financial regulation have many of the features of transnational epistemic clan structures. Central banking is increasingly comprised of 'knowledge communities' constructed around inter-paradigmatic discussions about theory, methods, and data, as central banks' organizational, territorial, and cultural boundaries blur with co-equal central bankers working closely together from project to project (Marcussen 2006, p. 10). G20 politicians did endorse the ideational shift, but they were not instrumental instigating it, as they were in the macroeconomic case of the 1970s. Third order macroprudential change was not a societal wide process. In Thurber's terms financial regulatory networks generally have the characteristics of policy subsystems, with low visibility, narrow scope for conflict, relatively low levels of conflict and a relatively small number of elite participants (Thurber, 1996, p.78). The macroprudential ideational shift, as we have established did resemble a rapid shift in beliefs and values, - what Baumgartner and Jones have termed 'a dramatic change in policy image.' However, unlike their case of nuclear policy this was not the result of a simultaneous shift in policy venue (Baumgartner and Jones, 1991.) Instead, in the macroprudential case, the policy venue for promoting rapid change in the dominant financial regulatory policy image remained more or less constant, - a specialist series of international expert networks. These venues and established elites remained in the driving seat in forwarding regulatory proposals, because it was to these expert venues, politicians turned for guidance. There was however a significant reconfiguration in who was prominent in these 
networks, in the plausibility of their case and their persuasive capacity. The pattern with the macroprudential ideational shift was that a number of officials who had either been openly publicly critical of the prior orthodoxy, such as Borio and his BIS collegues, or had been privately critical but had felt unable to speak out in the prevailing climate, such as the Bank of England's financial stability team, became more prominent and vocal and found that the climate of opinion amongst politicians, the public at large and senior central bank policy makers within their own networks were much more receptive to their arguments (Baker, 2013a). This process was accompanied by some evidence of reflexive learning by key pivotal individuals in the central banking community, as the weight of expert contributions amassed in the immediate post-crash period of 2009. One of the consequences of this willingness to engage in reflective learning was to keep central banks as key interlocutors in the field of financial governance and even expand their authority at the expense of microprudential supervisors, who are often lawyers and accountants, rather than macroeconomists (confidential interview BIS official, 7 February 2014), in a classic case of professional consolidation (Baker, 2014b). One notable example, was Bank of England governor Mervyn King, who had limited interest in financial regulation and had remained almost exclusively focused on monetary policy in the pre-crash period (Giles, 2012), but became converted to the macroprudential cause after the dramatic events of 2008 , as a consequence of his participation in international networks such as the FSB and the Basel Committee on Banking Supervision, as well as the work of the Bank's own financial stability team (Confidential interview Bank of England official, 27 $7^{\text {th }}$ March, 2014). As such this process resembled an 'insiders' coup d'etat, ${ }^{4}$, as macroprudential change agents acted as 'insider subversives' in Mahoney and Thelen's terminology. Such change agents work against an existing system from within it (termites in the basement), appearing supportive of existing arrangements but promoting new rules and ways of thinking on the edge of old ones (Mahoney and Thelen, 
2010, p.26). Such change agents also bide their time, disguising the true extent of their preferences, waiting for the moment at which they can actively advance their true preferences, playing a long game, as in the case of the Bank of England's financial stability team, but mobilising rapidly when an opportunity arises (Confidential interview Bank of England Official, 10 December, 2013.) Claudio Borio captured the fast moving nature of the macroprudential ideational shift, and how the perspective went from being relatively unpopular to being the primary policy frame due to the dramatic events of 2008. "A decade ago the term macroprudential was barely used and there was little appetite amongst policy makers and regulators to even engage with the concept, let alone strengthen macroprudential regulation....This swell of support [for macroprudential regulation] could not have been anticipated even as recently as a couple of years ago. The current financial crisis has been instrumental in underpinning it" (Borio, 2009, p.2 and p.32).

Those such as Borio, who had publicly made arguments critical of the pre-crash orthodoxy, also experienced a rise in their levels of professional esteem, due to their prior performance in making some accurate calls and appearing prescient (Baker, 2013a, Baker 2014b). Famously, Borio and his BIS colleague Bill White had sought to move the international consensus in a macroprudential direction, when they presented a paper at the Jackson Hole Conference of the Kansas City Federal Reserve in 2003, but received a cold reaction from the senior central bankers present including Alan Greenspan (Balzil and Schiessl, 2009). White, even earned the ironic moniker 'Merry Sunshine' at the Fed, in response to his repeated warnings about financial instability, but by 2009 had become one of the most in demand speakers in the world of central banking (Balzil and Schiessl, 2009).

The characteristics of the financial regulatory policy subsystem and the technical arcane nature of the subject matter, essentially allowed a coalition of public officials from central banks, related organizations and academic economists to change the dominant policy frame, 
relatively quickly and with little formal opposition. Macroprudential change agents were less dependent on building consensus, support and levels of understanding amongst wider societal and political actors, which macroeconomic policy's much higher political profile requires, although ultimately the technocratic nature of the macroprudential project may present long term legitimacy problems (Baker and Widamier, 2014). Opposition to third order macroprudential regulatory philosophy has been relatively mute. For example, one might expect most opposition to come from the private sector and from large banks. Yet, the Institute for International Finance (IIF), part lobby group and part think tank for large North American and European Banks, has generally been supportive of a macroprudential approach to financial regulation, at least in broad conceptual terms (IIF, 2011). Instead of contesting the broad philosophy behind macroprudential, the IIF has focused its attention on slowing and diluting first and second order policy change. The IIF has suggested that 'the science' in this area is at an early stage, while using capital as an instrument of macrostabilization was 'unprecedented and untested', requiring authorities to 'exercise great caution' (IIF, 2011, p.22). In national settings such as the UK, political parties and politicians, have not contested the need for macroprudential regulation, or its rationale, but bodies such as the Treasury Select Committee have taken a great interest in the operation of the new FPC and have sought to create mechanisms to call FPC policy makers to account, carving out an oversight role for themselves in the process. Ultimately, because first order policy settings and second policy instruments have implications for the day to day investment strategies and market operations of a variety of market actors, and the turf and standing of wider institutional and legislative actors, political contestation has been far more focused on appropriate first order policy settings and second order institutional policy arrangements, than on third order change. The result is a far more contested, contingent and even controversial sphere of first and second order macroprudential policy development, which of course may dilute macroprudential 
policy content, in substantive terms and stymie any potential paradigm shift (Baker, 2013b). Third order change without substantive first and second order policy movement would amount to little. Once again this is the reverse of the pattern in macroeconomic policy and both the differing nature of the crises and the different institutional and political characteristics of financial regulatory and macroeconomic policy systems as outlined here combine to provide reasons for that.

\section{Macroeconomic Policy and the Financial Crash of 2008}

In the area of macroeconomic policy, foundational assumptions have proved far more resilient to change, since the financial crash of 2008, than in the case of financial regulation, as Paul Tucker's statement indicated. The general pattern identified in this article, is of a far slower pace of learning in macroeconomic policy, not only due to the slow burning nature of macroeconomic problems, which often have complicated causal chains, but also because of the number of actors that have to consent to far reaching third order change in a macro policy system. There is certainly considerable evidence that macroeconomic learning has been a much slower and more pragmatic process. For example, as Hodson and Mabbett note, first order changes to the setting of new policy instruments and second order changes in the introduction of new macroeconomic policy instruments, were not accompanied by third change in the form of a fundamentally new understanding of how the economy works (Hodson and Mabbett, 2009). In the UK case fiscal policy discretionary measures following the crash amounted to only around 1.4 per cent of GDP, of the UK's ballooning deficit (OECD, 2009.) Reports of the Labour Party's reconversion to Keynesian demand management were therefore grossly exaggerated (Hodson and Mabbett, 2009, p.1058). 
In monetary policy, the turn to quantitative easing continues to reflect the limitations of conventional monetary policies under current circumstances, but it has not as yet entailed a jettisoning of the existing monetary policy framework (Hodson and Mabbett, 2009, p.1057). More recently debate has begun about the use of nominal income or GDP targets as a guide for monetary policy (Bean, 2013). At the same time IMF research increasingly raises questions about the practical use of inflation targeting, suggesting that targets of 2 per cent or below may have a detrimental distributional impact on those in the bottom part of the income stream, resulting in poor macroeconomic performance (IMF, 2014, Moghadam, Teja and Berkman, 2014, Kirshner, 2001). However, these questions are only being raised some five years after the financial crash of 2008, during which time the success and usefulness of the existing inflation targeting monetary policy regime has begun to be widely questioned, largely because inflation targeting has been redundant as a guide for policy for the last five years. In this respect, monetary policy frameworks are beginning to display the accumulated anomalies that Hall claims beset the Keynesian paradigm in the 1970s, even if there are still as yet no concrete plans to replace inflation targeting.

Fiscal policy too, is gradually becoming a more complex ideationally contested area. In the UK, after being critical of the coalition government's attempted deficit reduction strategy, based on a discourse of public spending 'crowding out' private investment, the current Labour opposition is now pledging to keep to the coalition's spending plans. Despite this move, the IMF has encouraged the UK government to slow down fiscal consolidation given low growth and prolonged stagnation in the 2008-13 period, pointing out that the UK has considerable fiscal policy space due to the length of debt maturities (Clift and Tomlinson, 2012). In this sense, post crash, the IMF has adopted a much more pragmatic line on fiscal policy emphasising, context-dependent, contingent, and inherently transient historical constructs, rather than doctrinaire notions of fiscal consolidation (Clift and Tomlinson, 2012, 
p.16.) Greater emphasis has been placed by Fund analysis on fiscal policy as an important potential 'counter cyclical' tool (Blanchard et al, 2010). The Fund has also argued that, 'those with room for fiscal policy manoeuvring, in terms of their fiscal accounts and credibility with markets, can reconsider the pace of consolidation' (IMF 2012, p.21). Nevertheless, despite the emergence of such alternative analyses and growing ideational contestation in the area of fiscal policy, the dominant pattern has been the emergence of a new era of austerity and a pattern of ideational stickiness drawing on notions of expansionary fiscal consolidations and Ricardian equivalence (Blyth, 2013, Farrell and Quiggins, 2012, Dellepiane-Avellaneda, 2014).

Linking the explosive banking and financial crash of 2008, to macroeconomic policy and problems is a less straight forward intellectual case to make, than pointing to a flawed intellectual frame for financial regulation and therefore is likely to require analysis and reflection on post-crash macroeconomic performance over a period of time, as long term evidence and data emerges. Moreover, as we saw at the beginning of the article, key expert authorities, such as central banks, have not had the same institutional incentives to question dominant macroeconomic practice, as they have in financial regulation. Based on the experience of the 1970s and the available evidence following the financial crash of 2008, it would seem that the three conditions identified by Hall in the 1970 s case, were not immediately present following the financial crash of 2008. First there was a dramatic malfunction of the banking and financial system, rather than a long gestation period of macroeconomic under performance and stagnation, although this of course may yet emerge through persistent poor growth for major economies and sustained deflation in the Eurozone ${ }^{5}$. Other scholars have suggested that sustained deflation in particular can create conditions ripe for elite persuasion strategies for significant macroeconomic policy change, again suggesting that the variety of crisis matter for the variety of ideational change we can expect to witness 
in policy making (Blyth, 2007). Second, there was little evidence of a 1+2 sequence of anomaly accumulation and subsequent prolonged prior macroeconomic experimentation with first and second order policy decisions outside of the existing macroeconomic paradigm in the run up to 2008. More recently, it is conceivable that we have now entered a phase of 'technocratic inter-paradigm borrowing', as the old framework certainly in monetary policy has gradually become redundant and difficult to operate, and the evidence cited above suggests as much (Hay, 2011). Third, largely because of the absence of the two prior conditions there was no broad consensus on the failure of previous macroeconomic policy frameworks and only initial stirrings of political dissatisfaction with prior macroeconomic approaches. There was certainly no politically feasible, or immediately appealing and intellectual coherent alternative, with the exception of some short-term limited emergency Keynesianism. Previous instances of significant macroeconomic ideational change, suggest macroeconomic discontent has to brew over time as problems and anomalies accumulate, alternative narratives and approaches are built, and processes of persuasion are embarked upon that results in some sort of politically viable consensus amongst the multiple actors that participate in the macro policy system of macroeconomic policy debate.

\section{Conclusion}

This article has argued that the interpretations of crisis that become dominant will partially be determined by the symptoms a particular crisis displays, as well as the institutional features of the policy system that have responsibility for particular areas of policy. As Reinhart and Rogoff have identified, financial crises take many different forms. They identify seven types of crises covering: inflation crises; currency crashes; currency debasement; asset price bubbles bursting; banking crises; external debt crises; and domestic debt crises (Reinhart and 
Rogoff, 2009). However, their classificatory schema is both mechanical and arbitrary, as they either rely on narrow quantitative measures, or equally narrowly defined events, to form their definitions. This not only obscures potential causal chains, and how crises can move around and flow into one another, but it also pays little attention to how crises come to be understood cognitively, and responded to, by a critical mass of societal and political actors, which in turn gives inter-subjective meaning to a crisis (Widmaier, Blyth and Seabrooke, 2007). A true political economy of financial crises therefore needs to examine how ideas are used by policy actors to interpret crises, but also how ideas in different policy domains change and respond to different forms of crisis in different ways. A more straight forward, simple distinction in terms of varieties of crisis, has been adopted here. A distinction has been drawn between explosive crises emanating from malfunctioning banking systems and private malinvestment, and slow burning crises of stagnation, declining living standards, falling wages and prices, or rising wages and prices, which involve a failure of government macroeconomic policies to meet stated targets, or objectives. These two forms of crisis can also obviously be connected and flow into one another, but they are unlikely to be interpreted in the same way, or to lead to the same patterns of ideational and institutional change.

In this respect, the existing literature has paid insufficient enough attention to how ideas interact with and respond to the material symptoms of crises, and how different policy sub systems can react and behave in different ways to different forms of crises. I have argued that the capacity for agents to affect change during periods of crisis is constrained by the type of crisis and its symptoms, as well as the institutional and political context that prevails in particular policy areas. The evidence presented here shows how different policy areas are subject to different political dynamics, different sequences and time frames, and become politically contentious in different ways. The paper has sought to demonstrate three specific differences between macroeconomic policy and financial regulation, drawing on Peter Hall's 
work, as illustrated in table 1 . The paper has hypothesised that fundamental macroeconomic change requires the presence of three conditions: persistent macroeconomic failure and stagnation over a considerable 5-10 year period; prior policy experimentation from outside of the existing paradigm that reveals the inadequacies and anomalies of the existing policy framework; and growing political dissatisfaction with the existing paradigm, combined with the construction of an enabling coalition pushing a genuinely intellectually coherent and politically appealing alternative, which in the field of macroeconomic policy takes time to assemble due to the presence of numerous potential veto players. In contrast financial regulation, as a policy subsystem behaves rather differently. Technical experts were able to act opportunistically and affect third order policy change and radically change the dominant policy frame and the assumptions on which it was based in a short period of time, with little signs of significant opposition. However, industry opposition and political contestation appears to be far more fierce in financial regulation over detail, than it is over broad parameters. Not only has third order change been quicker in the field of financial regulation, the sequencing that applies in macroeconomic policy has been reversed, while fights over the detail of policy appear far more contentious and contested than broad objectives. The explanation forwarded for this has emphasised that macroeconomic policy is more likely to respond to a slow burning crisis than dramatic banking crises, because this allows for complex causal chains to be interpreted and for political support for those interpretations to be built in diffuse macro policy systems. Time also allows for the policy experimentation to take place which further undermines an existing paradigm. In contrast, financial regulation has a policy system that can respond in a rapid and intellectually radically fashion to dramatic and explosive banking crises, but is then constrained by politically contested battles over points of detail. 


\section{Bibliography}

Aikman, D Haldane and Nelson, B (2011) "Curbing the Credit Cycle," Vox, Http://voxeu.org/index.php?q=node/6231, accessed $12^{\text {th }}$ May 2011.

BIS (2006) $76^{\text {th }}$ Annual Report, Basel, June.

Balls, E (1998) 'Open macroeconomics in an open economy'; Scottish Journal of Political Economy, 45, pp. 113-32

Baker, A (2013a) "The New Political Economy of the Macroprudential Ideational Shift," New Political Economy, 18:1, pp.112-139.

Baker, A (2013b) "The Gradual Transformation? The Incremental Dynamics of Macroprudential Regulation," Regulation \& Governance, 7:4, pp.417-434.

Baker, A (2014a) "Macroprudential Regulation," in Mugge, D (ed.) Europe's Place in Global Financial Governance, Oxford: Oxford University Press

Baker, A (2014b) "Esteem as Professional Currency and Consolidation: The Rise of the Macroprudential Cognoscenti" in Seabrooke, L and Henriksen, L (eds.) Professions in Transnational Governance, Cambridge: Cambridge Universitty Press (forthcoming).

Baker, A and Widmaier, W (2014) ““"The Hidden Institutionalist Roots of Macroprudential Ideas: Veblen and Galbraith on Regulation, Policy Success and Overconfidence," New Political Economy, DOI: $10.1080 / 13563467.2013 .796447$

Balizil, B and Schiessl, M (2009) "The Man Nobody Wanted to Hear: Global Banking Economist Warned of Coming Crisis," Spiegel online, 07/08, available at http://www.spiegel.de/international/business/0,1518,635051,00.html

Barwell, R (2013) Macroprudential Policy: Taming the wild Gyrations of credit flows, debt stocks and asset prices, Basingstoke: Palgrave

Baumgartner, F and Jones, B (1991) "Agenda Dynamics and Policy Subsystems," The Journal of Politics, 53:4, pp. 1044-1074.

Blyth, M (2002) Great Transformations: Economic Ideas and Institutional Change in the Twenty First Century, Cambridge: Cambridge University Press.

Blyth, M (2007) "Powering, Puzzling, or Persuading? The Mechanisms of Building Institutional Orders," International Studies Quarterly, 51:4, pp.761-777.

Blyth, M (2013a) Austerity: The History of a Dangerous Idea, Oxford: Oxford University Press

Blyth, M (2013b) "Paradigms and Paradox: The Politics of Economic Ideas in Two Moments of Crisis," Governance, 26:2, pp.197-215.

Bean, C (2013) "Nominal Income Targets: Old Wine in a New Bottle," Speech at the Institute of Economic Affairs, Conference on the State of the Economy, February 2013.

Bernanke, B (2011) "Implementing a Macroprudential Approach to Supervision and Regulation," 47 Annual Conference on Bank Structure and Competition, Chicago, Illinois, May 5. 
Blanchard, O., Dell'Ariccia, G.and Mauro, P. 2010. 'Rethinking Macroeconomic Policy' IMF Staff Position Note SPN/10/03 February 122010

Borio, C (2011) "Implementing a Macroprudential Framework: Blending Boldness and Realism," Capitalism and Society, 6;1, pp.1-23.

Borio, C (2009) "Implementing the Macroprudential Approach to Financial Regulation and Supervision," Banque de France, Financial Stability Review, No.13, September.

Borio, C and White, W (2004)"Whiter Monetary and Financial Stability: The Implications for Evolving Policy Regimes,” BIS working paper 147, Bank for International Settlements, Basel

Borio, C, Furfine, C and Lowe, P (2001) "Procyclicality of the Financial System and Financial Stability Issues and Policy Options," BIS Papers, no.1. March, pp.1-57.

Brunnemier, M Crockett, A, Goodhart, C. Persaud, A. Shin, H (2009) The Fundamental Principles of Financial Regulation. Geneva Report on the World Economy 11, Geneva: International Centre for Monetary and Banking Studies, London: Centre for Economic Policy Research.

Carney, M (2014) "One Mission, One Bank: Promoting the Good of the People of the United Kingdom," Mais Lecture, Cass Business School London, $18^{\text {th }}$ March, http://www.bankofengland.co.uk/publications/Documents/speeches/2014/speech715.pdf

Chwieroth, J (2010) "How do Crises Lead to Change? Liberalizing Capital Controls in the Early Years of New Order Indonesia," World Politics,62:3, pp.496-527.

Clement, P (2010) “The term 'macroprudential': origins and evolution,” BIS Quarterly Review, March, pp.59-67.

Constancio, V (2011) "Macroprudential Policy: Strengthening the Foundations, Enhancing the Toolkit and Taking Action," First Conference of the Macro-prudential Research Network (MaRs), Frankfurt, $5^{\text {th }}$ October.

Clift, B and Tomlinson, J (2007) "Credible Keynesianism? New Labour Macroeconomic Policy and the Political Economy of Coarse Tuning," British Journal of Political Science, 37:1, pp.47-69.

Clift, B and Tomlinson, J (2012) "The Politics of Fiscal Rectitude in Britain Since the Crisis: The Coalition's Mobilisation of Greek Myths and IMF Commentary on UK Fiscal Policy," paper on file with the author.

Datz, G (2012) 'The Narrative of Complexity in the Crisis of Finance: Epistemological Challenge and Macroprudential Policy Response', New Political Economy, DOI: $10.1080 / 1356347.2012 .710601$

De Laroisiere Group (2009) Report of the High Level Group on Financial Supervision in the EU, Brussels.

Dellepiane-Avellaneda, S (2014) "The Political Power of Economic Ideas: The Case of Expansionary Fiscal Contraction," British Journal of Politics and International Relations, DOI: $10.1111 / 1467-856 X .12038$ 
Eatwell, J (2009) "Practical Proposals for Regulatory Reform," in Subacchi, P and Monsarrat, A (eds). New Ideas for the London Summit: Recommendations to the G20 Leaders, London: Royal Institute for International Affairs Chatham, The Atlantic Council, pp.11-15.

Elliot, D (2011) “Choosing Among Macroprudential Tools," The Brookings Institute, available at http://www.brookings.edu/ /media/Files/rc/papers/2011/0607 macroprudential tools elliott/0607 m acroprudential_tools_elliott.pdf

Fama, E (1970) "Efficient Capital Markets: A Review of Theory and Evidence," Journal of Finance, Vol.25, No.2, pp.383-417.

Farrell, H and Quiggins, J (2012) "Consensus, Dissensus and Economic Ideas: The Rise and Fall of Keynesianism During the Economic Crisis," Paper on file with author.

Finnemore, M and Sikkink, K (1998) "International Norm Dynamics and Political Change," International Organization, 52:4, pp.887-917.

FSA (2009) “The Turner Review,” FSA: London.

FSF (2008) "Report of the Financial Stability Forum on Enhancing Market and Institutional Resilience," 7 April. Available at http://www.financialstabilityboard.org/publications/r 0804.pdf

FSF (2009) "Report on Addressing Procyclicality in the Financial System," FSB, Basel, April 2009, available at: http://www.financialstabilityboard.org/publications/r_0904a.pdf

FSB, BCBS, IMF (2011) “Macroprudential Policy Tools and Frameworks," Progress Report to G20, $27^{\text {th }}$ October.

Fama, E (1970). "Efficient Capital Markets: A Review of Theory and Empirical Work". Journal of Finance, Vol. 25, No. 2, pp. 383-417.

G20 (2009a) G20 Communiqué, Meeting of Finance Ministers and Central Bank Governors, Horsham, United Kingdom, 14 March 2009.

G20 (2009b) "Declaration on Strengthening the Global Financial System, Statement issues by G20 Leaders, 2 April, 2009 http://www.g20.utoronto.ca/2009/2009ifi.pdf

G30 (2009) Group of Thirty Financial Reform: A Framework for Financial Stability, Washington DC.

Gamble, A (2009) The Spectre at the Feast: Capitalist Crisis and The Politics of Recession, London: Palgrave

Giles, C (2012) "The Court of King Mervyn," Financial Times Weekend, 5 May. http://www.ft.com/cms/s/2/f853d068-94b7-11e1-bb0d-00144feab49a.html\#axzz319er7Ufh

Goodhart, C (2005) "Financial Regulation, Credit Risk and Financial Stability," National Institute Economic Review, No.192, pp.118-128.

Goodhart, Charles and Segoviano, Miguel A. (2004) "Basel and procyclicality: a comparison of the standardised and IRB approaches to an improved credit risk method.” Discussion paper, 524. 
Goodhart, L (2014) "Brave New World? Macroprudential Policy and the New Political Economy of the Federal Reserve," http://lucymgoodhart.files.wordpress.com/2013/10/goodhart_brave_fed_macro_pru_ripe_full.pdf

Haldane, A (2009) "Small Lessons From a Big Crisis," Remarks at the Federal Reserve Bank of Chicago, 45 ${ }^{\text {th }}$ Annual Conference, "Reforming Financial Regulation," 8 May 2009.

Haldane, A (2010) "The \$100 Billion Question," Bank of England Discussion Paper, Originally presented at the Institute of Regulation \& Risk, Hong Kong, March 2010.

Haldane, A (2012) 'A Leaf Being Turned,' Bank of England Discussion Paper, http://www.bankofengland.co.uk/publications/Documents/speeches/2012/speech616.pdf

Haldane, A (2013) “Macroprudential Policies: When and How to Use them?” Paper at Re-Thinking Macro II Conference, IMF Washington 16-17 April, http://www.imf.org/external/np/seminars/eng/2013/macro2/pdf/ah.pdf

Haldane, A (2014a) “Ambidexterity," Paper delivered at American Economics Association Conference, Philadelphia, 3 January.

Haldane, A (2014b) “Andy Haldane in Conversation with Andrew Gamble," Remarks made at the University of Sheffield, Sheffield Political Economy Research Institute, $20^{\text {th }}$ February.

Haldane, A and May, R (2011) “Systemic Risk in Banking Ecosystems,” Nature, 469, pp.351-355.

Hall, P (1993) "Policy Paradigm, Social Learning and the State: The case of economic policymaking in Britain," Comparative Politics, 25:3, pp.275-96.

Hanson, S Kahyap, A and Stein, J (2011) "A Macroprudential Approach to Financial Regulation," Journal of Economic Perspectives, 1, pp.1-26.

Hay, C (1996) "Narrating Crisis: The Discursive Construction of the 'Winter of Discontent," Sociology, 30:2, pp.253-277.

Hay, C (2011) "Pathology Without Crisis? The Strange Demise of the Anglo Liberal Growth Model," Government and Opposition, Vol.46, No.1, pp.1-31

Helleiner, E (2010) "A Bretton Woods Moment? The 2007-08 Crisis and the Future of Global Finance,” International Affairs, 86:3, (May), pp.619-636.

Hodson, D and Mabbett, D (2009) "UK Economic Policy and the Global Financial Crisis: Paradigm Lost?” Journal of Common Market Studies, 47:5, pp.1041-1061.

IIF (2011) "Macroprudential Oversight: An Industry Perspective," Submission to the International Authorities. Available at http://www.iif.com/regulatory/article+971.php

IMF. (2012) World Economic Outlook: Growth Resuming, Danger Remain Washington: IMF.

IMF (2014a) World Economic Outlook Washington: IMF

Kirshner, J (2001) “The Political Economy of Low Inflation,” Journal of Economic Surveys, 15:1, pp.41-70. 
Kuhn, T (1996) The Structure of Scientific Revolutions, $3^{\text {rd }}$ Revised Edition Chicago: University of Chicago Press.

Lawson, N (1992) The View from No.11: The Memoirs of a Tory Radical, London: Bantam

Lothian, T (2011) "Beyond Macroprudential Regulation: Three Ways of thinking about financial crisis, reform and regulation," Global Policy, 3:4, pp.410-420.

Lucas, R (1980) “Equilibrium in a pure currency economy,” Economic Inquiry, Vol.18, No.2, pp.203220.

Marcussen, M (2006) The Fifth Age of Central Banking in the Global Economy,' Paper presented at the conference 'Frontiers of Regulation', University of Bath, 7-8 Sept. 2006

Mahoney, J and Thelen, K (2010) “A Theory of Gradual Institutional Change,” in Mahoney J and

Minsky, H (1977) "The Financial Instability Hypothesis: An Interpretation of Keynes and an

Alternative to 'Standard' Theory," Nebraska Journal of Economics and Business, 16:1, pp.59-70.

Moghadam, R Teja, R and Berkmen, P (2014) “Euro Area - Deflation versus Lowinflation,” IMF

Direct blog, http://blog-imfdirect.imf.org/2014/03/04/euro-area-deflation-versus-lowflation/

Oliver, M and Pemberton , H (2004) "Learning and Change in $20^{\text {th }}$ Century British Economic Policy," Governance 17:3, pp.415-441.

OECD (2009) OECD Interim Economic Outlook, Paris: OECD

Panetta, F, Angelini, P, Albertazzi, U, Columba, F, Cornacchia, W, Di Cesare, A, Pilati, A, Salleo, C, Santini, G (2009) "Financial Sector Procyclicality: Lessons for the Crisis," Banca d' Italia, Occasional Papers

Persaud, A (2010) "The Rise and Apparent Fall of Macroprudential Regulation," http://www.voxeu.org/article/taking-macro-prudential-regulation-seriously

Persaud, A (2009) "Macroprudential Regulation: Fixing Fundamental Market and Regulatory Failures," Crisis Response (Note number 6), The World Bank Group, Financial and Private Sector Development, July.

Persaud, A (2000) "Sending the herd off the cliff edge: the disturbing interaction between herding and market-sensitive risk management systems," World Economics, 1;4, pp.15-26.

Reinhart, K and Rogoff, K (2009) This Time is Different: Eight Centuries of Financial Folly, Princeton: Princeton University Press

Schmidt, V (2008) "Discursive Institutionalism: The Explanatory Power of Ideas and Discourse," Annual Review of Political Science, 11, pp.303-326.

Seabrooke, L. and E. Tsingou. (2014) 'Distinctions, Affiliations, and Professional Knowledge in Financial Reform Expert Groups', Journal of European Public Policy 21(3), pp.389-407.

Thurber, J (1996) "Political Power and Policy Subsystems in American Politics," in in Thomas B. Birkland (ed.), Public Policy Course Syllabi (Washington, DC: American Political Science Association, 1998), pp. 211-238. 
Tucker, P (2011) “Discussion of Lord Turner's Lecture, 'Reforming Finance: Are We Being Radical Enough?" Clare Distinguished Lecture in Economics, Cambridge 18 February.

Turner, A (2011) “Reforming Finance: Are We Being Radical Enough?” Clare Distinguished Lecture in Economics and Public Policy, Cambridge, 18 February.

UN (2009) UN Commission of Experts on Reforms of the International Monetary and Financial Systems, Recommendations, New York: United Nations

White, W (2006) "Procyclicality in the Financial System: Do we need a new macrofinancial stabilisation framework?” BIS Working Paper, no.193, January.

Widmaier, W, Blyth, M and Seabrooke, L (2007) "Exogenous Shocks or Endogenous Constructions? The Meanings of Wars and Crises," International Studies Quarterly, 51, pp.747-759.

Youngman, P (2009) "Procyclicality and Value at Risk," Bank of Canada, Financial System Review.

\footnotetext{
${ }^{1}$ Amongst BIS officials who pushed hard for macroprudential philosophies a suspicion lingers that the central banking community accepted these idea, when previously they had been resistant, because of a calculation that macroprudential potentially takes some of the pressure and strain off monetary policy, and therefore prevents a serious or fundamental overhaul of monetary policy frameworks.

${ }^{2}$ See endnote 1.

${ }^{3}$ What is marked about the pre crisis period is how few cases of operational macroprudential policy such as the system of counter cyclical capital buffers or 'dynamic provisioning' in Spain, and India there were. These cases were outliers and subsequently held up as functioning examples of macroprudential policy. The predominant attitude towards macroprudential policy amongst advanced country regulators was one of scepticism.

${ }^{4}$ I am grateful to Mark Blyth for suggesting this insightful phrase.

${ }^{5}$ Note the scholarship of Blyth (2002) and Helleiner (2010) on the response to the Wall Street Crash and the Great Depression emphasises that the macroeconomic settlement of embedded liberalism and of the Bretton Woods agreement took over fifteen years to construct, following the initial point of financial distress in 1929.
} 